

\title{
Nature And Methods Of Financial And Economic Evaluation Of Investment Projects
}

\author{
Ibodulla Ismatullayevich Soliyev \\ Candidate Of Economic Sciences, Head Of The Department Of Economics, Namangan State \\ University, Uzbekistan
}

Ilhom Ibroximovich Nurmatov

Master Of Namangan State University, Uzbekistan

Copyright: Original content from this work may be used under the terms of the creative commons attributes 4.0 licence.

\section{ABSTRACT}

This article provides clear information on the nature of financial and economic evaluation of investment projects, and develops definitions by type of evaluation.

\section{KEYWORDS}

Investment, project, valuation, discounting, internal rate of return, accounting profitability, indicator.

\section{INTRODUCTION}

The content of the financial and economic evaluation of any investment project is to find an answer to a very simple question, namely, whether future cash inflows will cover current expenses. In countries with developed market economies, methods of investment evaluation based on comparing the profitability of investments in different projects are widely used. An alternative to investing in this or that project is to invest in other facilities, as well as to invest in a bank with a certain interest rate or convert them into securities. 
From this point of view, methods of evaluating the effectiveness of investment projects are methods of determining the feasibility of investing in various facilities (projects, activities) in terms of profitability and cost recovery. In determining the effectiveness of investments, it is not enough to use separate indicators that characterize only some aspects of them. Therefore, several methods and a system of indicators are used to evaluate the effectiveness of investment projects.

\section{MAIN PART}

The reason for the introduction of such a condition is that in practice the implementation of most investment projects reduces or eliminates the possibility of implementing other projects. Such investment projects are called conflicting projects. Mutually conflicting projects also include projects that envisage different ways for a firm to achieve a particular end goal. The reason for the conflict of various projects is the limited resources of the enterprise. Firms select projects not only on the basis of absolute efficiency, but also on the basis of the losses they may see due to the inability to implement other projects due to lack of funding. In other words, the firm selects investment projects based on the criterion of relative efficiency. Another condition that we need to consider before embarking on a study of methods for determining the effectiveness of an investment is that in the process, all costs and revenues associated with the project are considered to be monetary.

\section{RESULTS AND DISCUSSION}

The process of calculating the future value of the funds invested today is a form of financial calculation called discounting. The second type of discounting is the reverse process of calculating the future value, which allows you to calculate the current value of the amount to be received in the future. It calculates how much you need to invest today to have a certain amount in the future. Of course, the amount to be received in the future should not be more than the amount of investment we are spending on profitable work today and the amount of return we expect. This type of discounting is called calculating the present value or determining the present, discounted value. To perform such a calculation, an inverse formula is used relative to the formula for calculating the next value.

$$
P V_{n}=\frac{F V_{n}}{(1+k)^{n}}=F V_{n} \cdot \frac{1}{(1+k)^{n}}
$$

Here: $P V_{n}-n$ the present value of the amount to be received after the year (discount rate) $k \quad$ when equal to $n$ years later $F V_{n}$ the amount of investment that needs to be made today to get the amount);

$F V_{n}-n$ the amount to be received after the year.

Agar $k$ this formula will only make sense if it reflects the level of income we can actually get when we spend our money on an investment project that is convenient for us.

The internal rate of return is the rate at which the present value of cash inflows is equal to the present value of cash outflows. In other words, it is a ratio that ensures that the present value of the net proceeds from the investment in the project is equal to the present value of the 
investment. A calculated value $I R R<k$ бўлca, инвестициялаш зарарли, $I R R>k \quad$ The investment will be profitable when. To calculate it, the formulas used in the calculation of the net present value are used. However, at the given minimum interest rate (discount rate) instead of discounting cash flows, the interest rate (discount) NPV is found to be zero. Thus, IRR - such a quantity of the discount coefficient that $N P V=0$ In this case, the investor on the project can act on their own. Agar NPV $<0$ if not, the project will be rejected, otherwise the project will be considered useful.

Therefore, the indicator cannot be used as the main method of assessing the effectiveness of investments. It should be noted that the first shortcoming in the calculation of the payback period of investments can be corrected. For this, cash flows are discounted. Return on investment is the second simplest (static) indicator for evaluating projects. In the literature, the average rate of return on investment is the calculated rate of return. also referred to. Through this indicator, investments are evaluated not on the basis of cash inflows, but on the basis of the amount of income of the firm, which is an accounting indicator. It can be concluded from the name of the indicator that it represents the ratio of the average amount of income of the firm to the average amount of investment in the accounting report. This figure is determined using the following formula:

$$
R O I=\frac{E B I T(1-C)}{\left(A_{B}-A_{A}\right) \div 2}
$$

Where:: EВIT ( ингл.earnings before interest and tax) - the amount of the firm's profit before it makes interest and tax payments (or after taxes, but before interest payments); tax rate (given in coefficients);

$A_{B}, A_{A}$ - the value of assets at the beginning and end of the year. The difference between these two amounts indicates the size of the investment cost. The application of the indicator is based on comparing its calculated level with the standard levels of profitability for the organization. If this figure is greater than the standard accepted by the organization, the project is considered acceptable. The reason why this indicator is still widely used in many countries around the world is as follows:

ROI - The shortcomings of the indicator are a reflection of its advantages. That is, when comparing investment projects using this indicator:

- the fact that the value of money is not the same at different times is not taken into account;

- projects with different service life are denied, ie the fact that two projects with the same profitability, one for 5 years and the other for 10 years, does not reflect this figure.

Also, the accounting return on investment is aimed at obtaining results that meet the requirements of shareholders and other "outsiders" without characterizing the real change in the firm's wealth.

Only the combined use of all methods of evaluating the considered investment projects will allow to draw a clear conclusion about the effectiveness or ineffectiveness of the projects. 


\section{CONCLUSIONS}

In conclusion, it is important to increase the efficiency of investment projects through the widespread use of types and methods of evaluation of investment projects, as well as the joint use of all methods of evaluation.

First, it is easy to calculate and does not require complex calculations such as discounting. However, if certain conditions are met, the calculated amount will be very close to the amount;

Second, if the investment is made in the form of perpetuity as equal amounts of annual cash inflows; Third, if the accumulated depreciation is sufficient to replace obsolete equipment without additional funds;

Fourth, if there is no change in the amount of working capital during the period of investment. Statistical methods of project evaluation should provide additional information on the project.

\section{REFERENCES}

1. Umarkulov, Kodirjon Maxamadaminovich, 2018. "A Study on the Dynamics of Foreign Trade and the Issues of Regional Economic Integration in Central Asia," Working Papers 18-5, Korea Institute for International Economic Policy.

2. Umarkulov, K. M. (2018). A Study on the Dynamics of Foreign Trade and the Issues of Regional Economic Integration in Central Asia (No. 18-5).

3. Umarkulov, K. M. (2018). A Study on the Dynamics of Foreign Trade and the Issues of Regional Economic Integration in Central Asia. [KIEP] Working Paper, 18(05), 0-0.
4. Revetria, R. O. B. E. R. T. O., Maxamadaminovich, U. K., \& Mirzaliyeva, G. U. L. N. O. R. A. (2014, January). Production Advantages in Textile and Light Industry and Features of Effective using of them in Uzbekistan. In Proceedings of the 8th International Conference on Management, Marketing and Finances (MMF'14), Cambridge, MA, USA (pp. 29-31).

5. Сирожиддинов, К. И., \& Имомов, Р. Н. (2014). Финансовая поддержка фермерских хозяйств в условиях либерализация экономики в Узбекистане. Молодой ученый, (1), 425-426.

6. Солиев, И. И., \& Сирожиддинов, К. И. (2015). Благоприятный инвестиционный климат-важный фактор макроэкономического развития. Молодой ученый, (17), 461-463.

7. Хусаинов, М. А., \& Сирожиддинов, И. К. (2016). Инновационные факторы экономического развития и их особенности в регионе. Молодой ученый, (11), 1063-1065.

8. Солиев, И. И. (2014). Основные направления государственной поддержки инновационных процессов в сфере связи и информатизации Узбекистана. Молодой ученый, (3), 548549.

9. Soliyev, I. I., \& Shokirov, A. (2018). THE MAIN FEATURES OF INNOVATION RISKS. Теория и практика современной науки, (1), 773775.

10. Soliyev, I. I. (2017). INVESTMENTS AND INNOVATIONS OF THEIR MUTUAL RELATIONS. Теория и практика современной науки, (5), 975-977.

11. Солиев, И. И. (2017). INNOVATIVE ACTIVITY AS OBJECT OF INVESTMENT. Теория $и$ 
практика современной науки, (5), 972975.35.

12. Sirojiddinov, K. I., \& Mirsoliev, A. A. (2020). Role Of Exports Of Fruit And Vegetable Products In Ensuring The Sustainability Of Foreign Trade. The American Journal of Interdisciplinary Innovations and Research, 2(08), 34-37.

13. Sirojiddinov, I. K., \& Sirojiddinov, K. I. (2020). Institutional Transformations In The Fruit And Vegetable Industry And Their Impact On Mitigating The Consequences of The Coronavirus Pandemic In Uzbekistan. The American Journal of Applied sciences, 2(08), 15-20.

14. Sirojiddinov, K. I., \& Imomov, R. N. (2020). Some Aspects of The Formation of Agricultural Clusters In The Republic of Uzbekistan. The American Journal of Agriculture and Biomedical Engineering, 2(08), 39-43.

15. Сирожиддинов, К. И. (2019). ORGANIZATION OF MARKETING RESEARCHES IN AGRICULTURE USTIVARIOUS DIRECTIONS OF DEVELOPMENT. Scientific Bulletin of Namangan State University, 1(8), 143-149.

16. Сирожиддинов, К. И. (2019). ORGANIZATION OF MARKETING RESEARCHES IN AGRICULTURE USTIVARIOUS DIRECTIONS OF DEVELOPMENT. Scientific Bulletin of Namangan State University, 1(8), 143-149.

17. Tursunalievich, A. Z., Bulturbayevich, M. B., Ismatullayevich, S. I., Urayimovich, B. O., \& Yokubovna, Y. H. (2021). Use of Gravitation Models in the Development of Tourism and Recreation. Annals of the Romanian Society for Cell Biology, 3124-3143.

18. Ismatullaevich, S. I., \& Yakubovich, Y. A. (2019). The role of innovative activity in the
Socio-Economic development of society. ACADEMICIA: An International Multidisciplinary Research Journal, 9(4), 9398.

19. NARZULLAEV, N., \& SOLIYEV, I. (2020). Innovation Strategies as a Necessary Condition of Modern Management. International Journal on Orange Technologies, 2(12), 45-47.

20. Soliyev, I. I., \& Ganiev, B. B. (2021). KEY FACTORS INFLUENCING ECONOMIC DEVELOPMENT.

21. Umarkulov, K. M. (2021). The Role Of Free Economics In The Development of The National Economy. The American Journal of Applied sciences, 3(04), 145-151.

22. Umarkulov, K. M., \& Khayrullaeva, Y. S. (2021). Ways To Effectively Use Industry Innovations. The American Journal of Interdisciplinary Innovations and Research, 3(04), 107-113.

23. Kurbonovich, Tozhiboev K., and Tolliboev S. T. Ogli. "Effective Use of Investment in the Development of the Territory of the Economy." JournalNX, 2021, pp. 121-125.

24. Тажибаев K. MEBA BA САБЗАВОТЧИЛИКДА

АГРОКЛАСТЕРЛАРНИ ТАШКИЛ ЭТИШ САМАРАДОРЛИГИ //Scientific Bulletin of Namangan State University. - 2020. - T. 2. №. 3. - C. 238-242.

25. Сирожиддинов К. И., Тажибаев К. Қ. ИСПОЛЬЗОВАНИЯ ВОЗМОЖНОСТЕЙ МАРКЕТИНГА И КООПЕРАЧИЙ В СЕЛЬСКОМ ХОЗЯЙСТВЕ //Scientific Bulletin of Namangan State University. - 2020. - T. 2. - №. 11. - C. 121-132.

26. Сирожиддинов К., Тажибаев К. қИШлОқ ХЎЖАЛИГИ КИЧИК БИЗНЕС СУБЪЕКТЛАРИДА МАРКЕТИНГ ФАОЛИЯТИНИ ТАШКИЛ ЭТИШ //Scientific 
Bulletin of Namangan State University. 2020. - T. 2. - №. 3. - C. 242-248.

27. Сирожиддинов, $\mathrm{K}$ and Тажибаев, Комилжон (2020) "ҚИШЛОҚ ХЎЖАЛИГИ КИЧИК БИЗНЕС СУБЪЕКТЛАРИДА МАРКЕТИНГ ФАОЛИЯТИНИ ТАШКИЛ ЭТИШ," Scientific Bulletin of Namangan State University: Vol. 2 : Iss. 3 , Article 47. Available at: https://uzjournals.edu.uz/namdu/vol2/iss3/4 7

28. Сирожиддинов, $\mathrm{K}$ and Тажибаев, Комилжон (2020) "ҚИШЛОҚ ХЎЖАЛИГИ КИЧИК БИЗНЕС СУБЪЕКТЛАРИАА МАРКЕТИНГ ФАОЛИЯТИНИ ТАШКИЛ ЭТИШ," Scientific Bulletin of Namangan State University: Vol. 2 : Iss. 3 , Article 47. Available at: https://uzjournals.edu.uz/namdu/vol2/iss3/4 7 